\title{
Prolactin response to synthetic TRF in pregnant ewes
}

\author{
W. A. Chamley* \\ Reproduction Research Section, University of Melbourne, S.S. Cameron Laboratory, \\ Werribee, Australia 3030
}

Summary. The prolactin secretion response to TRF was similar at all stages of pregnancy (Days 40, 66, 102 and term).

\section{Introduction}

As pregnancy continues in ewes, there is a progressive decrease in the LH and FSH response to synthetic LH-RH (Chamley, Findlay, Cumming, Buckmaster \& Goding, 1974a; Chamley, Findlay, Jonas, Cumming \& Goding, 1974b). These observations, for LH at least, have been confirmed for pregnant (Jenkin \& Heap, 1974) and lactating (Pelletier \& Thimonier, 1973; Pant, Hopkinson \& Fitzpatrick, 1973) ewes. The response of other pituitary hormones to releasing peptides administered during pregnancy has not been reported, and the present study was undertaken to determine whether there is any change in the prolactin response of the pituitary to synthetic TRF during pregnancy in the sheep.

\section{Materials and Methods}

The experiments were conducted in a closed shed with Merino ewes which were penned individually and allowed access to food and water at all times. The ewes were brought into the shed 1 week before each experiment and one jugular vein was cannulated with silastic tubing. During that week, the animals were handled frequently to reduce the likelihood of spontaneous prolactin release to fright or stress during the experimental period (Bryant, Linzell \& Greenwood, 1970). The 12 ewes each received an intravenous injection of synthetic TRF (Beckman Bioproducts, California) at Days 40 (Group A, 3 ewes), 66 (Group B, 3 ewes), 102 (Group C, 3 ewes) or term (Group D, 3 ewes). The term animals all lambed within 5 days of treatment.

Blood samples $(10 \mathrm{ml})$ were drawn from the jugular vein catheter at intervals of $30 \mathrm{~min}$, and starting at $150 \mathrm{~min}$ before the TRF injection $(0 \mathrm{~min})$. The TRF was injected into the noncannulated

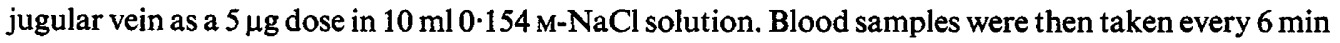
between 0 and $+24 \mathrm{~min}$, every $15 \mathrm{~min}$ between +90 and $+120 \mathrm{~min}$ and at +150 and $+180 \mathrm{~min}$. The heparinized samples were centrifuged and the plasma was stored at $-12^{\circ} \mathrm{C}$ until assay.

Prolactin was measured by a solid-phase radioimmunoassay (Fell et al., 1972). Under the assay conditions used, non-specific binding of ${ }^{125} \mathrm{I}$-labelled prolactin was $<10 \%$ of the counts bound to antibody at the zero point of the standard curve. The antibody used showed no cross-reaction with purified ovine LH and a $2 \%$ cross-reaction with ovine growth hormone (NIH-GH-S8) (Fell et al., 1972). The limit of sensitivity of the standard curve was $2.0 \mathrm{ng} / \mathrm{ml}$ and all samples were measured within a range on the standard curve where the within-assay coefficient of variation was $<10 \%$. This required repeated assays of some samples after appropriate dilution with $0.01 \mathrm{M}$-sodium phosphate buffer, $\mathrm{pH} 7 \cdot 4$. The between-assay coefficient of variation did not exceed $16 \%$.

A basal hormone level was calculated as the mean of the pretreatment values. The prolactin values for each ewe after TRF treatment were plotted individually and the points connected by straight lines.

* Present address: Pacific Biomedical Research Center, University of Hawaii, 1993 East West Road, Honolulu, Hawii 96822, U.S.A. 
The prolactin response was then calculated as the area between each response curve and the respective basal level up to $330 \mathrm{~min}$ (Hooley et al., 1974). Differences in response areas and/or means were tested for significance by Student's $t$ test (Snedecor \& Cochran, 1968).

\section{Results}

These are shown in Table 1. In the ewes treated at 40,66 or 102 days of gestation there were no significant differences in the mean prolactin concentrations in samples taken before treatment, but the pretreatment value for the term ewes was significantly higher $(P<0.01)$ than that for any of the other groups.

Table 1. Plasma prolactin levels (mean \pm s.e.m., number of samples in parentheses) in groups of pregnant ewes (3/group) treated with $5 \mu \mathrm{g}$ synthetic TRF at different stages of gestation

\begin{tabular}{ccccc}
\hline $\begin{array}{c}\text { Time relative to } \\
\text { TRF treatment } \\
\text { (min) }\end{array}$ & Group A (Day 40) & Group B (Day 66) & Group C (Day 102) & Group D (Term) \\
\cline { 2 - 5 } & $104 \cdot 4 \pm 7 \cdot 0(24)$ & $101 \cdot 9 \pm 23 \cdot 0(22)$ & $78 \cdot 8 \pm 37 \cdot 1(21)$ & $\dagger 242 \cdot 8 \pm 19 \cdot 2(20)$ \\
-150 to 0 & $* * * 313 \pm 25 \cdot 5(12)$ & $228 \cdot 7 \pm 42 \cdot 3(12)$ & $* 237 \cdot 5 \pm 24 \cdot 7(16)$ & $252 \cdot 8 \pm 21 \cdot 3(12)$ \\
0 to +24 & $116 \cdot 6 \pm 6 \cdot 2(9)$ & $* * 292 \cdot 7 \pm 68 \cdot 2(6)$ & $108 \cdot 9 \pm 20 \cdot 2(12)$ & $* 304 \pm 21 \cdot 9(9)$ \\
+30 to +60 & $126 \pm 3 \cdot 8(6)$ & $226 \pm 77 \cdot 0(6)$ & $28.9 \pm 10 \cdot 3(6)$ & $233 \cdot 4 \pm 23 \cdot 5(9)$ \\
+90 to +120 & $187 \cdot 7 \pm 62 \cdot 1(6)$ & $103 \cdot 4 \pm 46 \cdot 6(5)$ & $36 \pm 13 \cdot 6(8)$ & $179 \cdot 7 \pm 44 \cdot 3(4)$ \\
+150 to +180 & & & & \\
\hline
\end{tabular}

Values significantly different from pretreatment level for that group: ${ }^{*} P<0.05,{ }^{* *} P<0.01,{ }^{* * *} P<0.001$.

$\dagger$ Value significantly different from other pretreatment values, $P<0.01$.

Compared to the respective pretreatment levels, a significant elevation in prolactin following TRF administration was seen in all groups. In Groups $A$ and $C$ the change occurred within 24 min, while in Groups $B$ and $D$ the change was less marked and maximum values were reached after $24 \mathrm{~min}$ (Table 1). $\mathrm{By}+120$ min prolactin levels in Groups $\mathrm{A}$ and $\mathrm{C}$ were comparable to or lower than the mean pretreatment levels and changes beyond this point were not significant. In Groups $B$ and $D$ low values were not reached until after $+120 \mathrm{~min}$. Although there was a large between-animal variation, there were no significant differences in the prolactin responses of the various groups on the basis of area units.

\section{Discussion}

In these experiments, ewes at all stages of gestation showed a prolactin response to synthetic TRF and it seems probable therefore that prolactin synthesis occurs throughout pregnancy. While there was some between-animal variation, the response profiles for most animals were similar to those described for anoestrous ewes (Fell, Findlay, Cumming \& Goding, 1973). The pituitary response to synthetic TRF given during pregnancy is therefore markedly different from that to LH-RH (Chamley et al., 1974a, b).

Chamley, Jonas \& Parr (1976) suggested that, during pregnancy in the ewe, a mechanism became operative so that LH synthesis was selectively inhibited. This suggestion was based on the fact that total pituitary LH decreased as pregnancy progressed and reached a low point (approximately $5 \%$ of the LH content for non-pregnant controls) at 120-135 days of gestation, although no parallel change was seen in pituitary levels of FSH or growth hormone. The present results show that prolactin synthesis is also unaffected and further support the contention of a selective inhibition of LH synthesis.

This work was supported by the Australian Wool ResearchTrust Fund. I thank Dr J. Cerini, Ms J. Burhop and Ms E. Wilson for their help, and the Director of Agriculture, Victoria, for facilities. 


\section{References}

Bryant, G.D., Linzell, J.L. \& Greenwood, F.C. (1970) Plasma prolactin in goats measured by radioimmunoassay: the effect of teat stimulation, mating behavior, stress, fasting and of oxytocin, insulin and glucose injections. Hormones 1, 26-35.

Chamley, W.A., Findlay, J.K., Cumming, I.A., BUCKMASTER, J.M. \& Goding, J.R. (1974a) Effect of pregnancy on the LH response to synthetic gonadotropin releasing hormone. Endocrinology 94, 291293.

Chamley, W.A., Findlay, J.K., Jonas, H.A., Cumming, I.A. \& GoDING, J.R. (1974b) Effect of pregnancy on the FSH response to synthetic gonadotropin releasing hormone in ewes. J. Reprod. Fert. 37, 109-110.

Chamley, W.A., Jonas, H.A. \& Parr, R.A. (1976) Content of LH, FSH and growth hormone in the pituitaries of pregnant and anestrous sheep. Endocrinology 98, 1535-1538.

Fell, L.R., Beck, C., Brown, J.M., CATt, K.J., Cumming, I.A. \& Goding, J.R. (1972) Solid-phase radioimmunoassay of ovine prolactin in antibodycoated tubes. Prolactin secretion during estradiol treatment, at parturition and during milking. Endocrinology 91, 1329-1336.
Fell, L.R., Findlay, J.K., Cumming, I.A. \& Goding, J.R. (1973) Effect of synthetic TRF on prolactin release in the sheep. Endocrinology 93, 487-491.

Hooley, R.D., BaXter, R.W., Chamley, W.A., Cumming, I.A., Jonas, H.A. \& FindLAY, J.K. (1974) FSH and LH response to gonadotropin-releasing hormone during the ovine estrous cycle and following progesterone administration. Endocrinology 95, 937942.

Jenkin, G. \& HeAP, R.B. (1974) The lack of response of the sheep pituitary to LH-releasing hormone stimulation in gestation and early lactation: the probable role of progesterone. J. Endocr. 61, xii.

PANT, H.C., Hopkinson, C. \& FitzPatrick, R.J. (1973) Suppression of LH release induced by luteinizing hormone releasing hormone (LH-RH) in ewes during lactation. Acta endocr., Copenh., Suppl. 177, 298.

Pelletier, J. \& Thimonier, J. (1973) Comparison of induced preovulatory $\mathrm{LH}$ discharge in lactating and dry sheep during seasonal anoestrus. J. Reprod. Fert. 33, 310-313.

SNedeCOR, G.W. \& COCHRAN, W.G. (1968) Statistical Methods, 6th edn, p. 120. Iowa State University Press, Ames.

Received 6 July 1977 